\title{
NOP10 Gene
}

National Cancer Institute

\section{Source}

National Cancer Institute. NOP10 Gene. NCI Thesaurus. Code C152090.

This gene plays a role in both ribosome biogenesis and telomere maintenance. 